University of Nebraska - Lincoln

DigitalCommons@University of Nebraska - Lincoln

Biological Systems Engineering: Papers and

Publications

Biological Systems Engineering

$2-2004$

\title{
Fatty Acid Composition and Oxidation of Lipids in Korean Catfish
}

K. T. Hwang

Chonbuk National University, Korea, kthwang@chonbuk.ac.kr

J. E. Kim

Chonbuk National University, Korea

S. G. Kang

Mokpo National University, Korea

S. T. Jung

Mokpo National University, Korea

H. J. Park

Korea University, Seoul, Korea

See next page for additional authors

Follow this and additional works at: https://digitalcommons.unl.edu/biosysengfacpub

Part of the Biological Engineering Commons

Hwang, K. T.; Kim, J. E.; Kang, S. G.; Jung, S. T.; Park, H. J.; and Weller, Curtis L., "Fatty Acid Composition and Oxidation of Lipids in Korean Catfish" (2004). Biological Systems Engineering: Papers and Publications. 184.

https://digitalcommons.unl.edu/biosysengfacpub/184

This Article is brought to you for free and open access by the Biological Systems Engineering at DigitalCommons@University of Nebraska - Lincoln. It has been accepted for inclusion in Biological Systems Engineering: Papers and Publications by an authorized administrator of DigitalCommons@University of Nebraska Lincoln. 


\section{Authors}

K. T. Hwang, J. E. Kim, S. G. Kang, S. T. Jung, H. J. Park, and Curtis L. Weller 


\title{
Fatty Acid Composition and Oxidation of Lipids in Korean Catfish
}

\author{
K. T. Hwang, ${ }^{1}$ J. E. Kim, ${ }^{1}$ S. G. Kang, ${ }^{2}$ S. T. Jung, ${ }^{2}$ H. J. Park, ${ }^{3}$ and C. L. Weller ${ }^{4}$ \\ 1. Department of Food Science and Human Nutrition and Institute for Molecular Biology and Genetics, \\ Chonbuk National University, Jeonju, Jeonbuk, 561-756, Korea \\ 2. Department of Food Engineering and Food Industrial Technology Research Center, \\ Mokpo National University, Muan, Chonnam, 534-729, Korea \\ 3. Graduate School of Biotechnology, Korea University, Seoul, 136-701, Korea \\ 4. Department of Biological Systems Engineering, University of Nebraska, Lincoln, Nebraska 68583 \\ Corresponding author - K.T. Hwang, Department of Food Science and Human Nutrition, College of Human Ecology, \\ Chonbuk National University, Jeonju, Jeonbuk, 561-756, South Korea; email kthwang@chonbuk.ac.kr
}

\begin{abstract}
This study determined the lipid content and FA composition of muscle and a mixture of muscle and viscera from Korean catfish as well as lipid oxidation and hydrolysis. Lipid content and FA compositions in Korean catfish, which were purchased every month or two during September 1999-July 2000, were analyzed. Lipid oxidation and hydrolysis were determined as PV, thiobarbituric acid value, and FFA in the muscle and the mixture during storage at $2^{\circ} \mathrm{C}$ for 12 $\mathrm{d}$ and $-14^{\circ} \mathrm{C}$ for $9 \mathrm{wk}$. Lipid contents of the muscle and the mixture were $3.2(\mathrm{w} / \mathrm{w})$ and $5.4 \%$, respectively. Oleic acid was the most abundant FA in the catfish lipids, constituting $28.0 \%(\mathrm{w} / \mathrm{w})$ of total FA in the muscle and $25.6 \%$ in the mixture, followed by palmitic acid and linoleic acid, amounting to 20.2 and $12.2 \%$, respectively, in the muscle and 20.2 and $12.5 \%$ in the mixture. EPA and DHA were 3.2 and $6.8 \%$, respectively, in the muscle and 3.5 and $8.1 \%$ in the mixture. Seasonal variation in lipid contents and FA composition was minimal in catfish. Lipids in minced catfish oxidized and hydrolyzed readily at $2^{\circ} \mathrm{C}$. Inclusion of viscera into the muscle increased lipid oxidation and hydrolysis. Frozen storage at $-14^{\circ} \mathrm{C}$ and addition of ascorbic acid both reduced lipid oxidation. Frozen storage retarded lipid hydrolysis in catfish.
\end{abstract}

Keywords: Catfish, fatty acid, lipid hydrolysis, lipid oxidation, viscera

Catfish is one of the most popular freshwater fish for human consumption throughout the world. It is rich in lipids and a good source of unsaturated FA, including n-3 FA that have a positive impact on human health.

The lipid content and FA composition in catfish are affected by various factors such as their environment (1), size of fish (2), species (3), tissue (4), and diet (5). Lipid contents of fatty saltwater fish such as mackerel and menhaden vary by season $(6,7)$ but minimal seasonal variation of lipid content and FA composition in catfish has been reported $(2,8)$.

Although only catfish muscle is generally acceptable as human food, whole fish including viscera can be used in the manufacture of fish paste or extraction of fish oil to increase yields. Viscera of catfish, including digestive tract, liver, gallbladder, and storage fat, are potential sources of lipids with higher n-3 FA content; Choi et al. (4) reported that viscera of catfish contained more lipids and PUFA than muscle. Sathivel et al. (9) analyzed the FA composi- tion of crude oil recovered from whole viscera, which constituted approximately $14 \%$ by weight (wet basis) of a live catfish, and each component of the viscera and reported that total unsaturated FA in visceral oil amounted to 261.3 $\mathrm{mg} / \mathrm{g}$ (dry basis) compared with that of fillet $(259.3 \mathrm{mg} / \mathrm{g}$ ).

Lipids in fish are generally susceptible to oxidation owing to their high degree of unsaturation. Once viscera are combined with fish muscle, the mixture may experience accelerated lipid oxidation. More severe lipid hydrolysis of muscle also is expected when viscera are included. Hwang and Regenstein (7) reported that ascorbic acid was a very effective antioxidant in minced menhaden along with lowtemperature storage and vacuum packaging. According to Hwang and Regenstein (10), lipid hydrolysis in minced mackerel was most influenced by storage temperature if hydrolytic enzymes were not heat-deactivated.

In this study, lipid contents and FA compositions in muscle and in a mixture of muscle and viscera from Korean catfish were examined over the course of a year. In addition, levels of lipid oxidation and hydrolysis in the muscle and in the mixture of muscle and viscera from catfish were determined during refrigerated $\left(2^{\circ} \mathrm{C}\right)$ and frozen $\left(-14^{\circ} \mathrm{C}\right)$ storage.

\section{Materials and Methods}

Materials and reagents. Live catfish (Silurus asotus; 300$400 \mathrm{~g}$ each), aquacultured outdoors (exposed to ambient temperatures) in Jeonju, Korea, were purchased every month or two during September 1999-July 2000 from the same producer. FAME standards were purchased from $\mathrm{Nu}-$ Chek-Prep Inc. (Elysian, MN).

Fish sample preparation for analyses for proximate composition and FA composition. Six catfish were used each time. Muscle was recovered from each of three fish, and skin, head, bone, and viscera were discarded. Muscle and viscera (including liver, digestive tract, gallbladder, and storage fat) were collected from each of the other three fish. To produce a homogeneous sample, the muscle and mixture samples from each fish were minced using a blender 
(FM860T; Hanil Electronic, Seoul, Korea) for $1 \mathrm{~min}$. The minced samples were placed in plastic cups $(3.5 \mathrm{~cm}$ internal diameter; $3.8 \mathrm{~cm}$ internal height) with screw caps and stored at $-40^{\circ} \mathrm{C}$ until used. Proximate composition analysis and lipid extraction for FA composition analysis were done within a week after mincing.

Proximate composition analysis. Moisture content, crude protein, and crude lipids were determined by an oven-drying method, micro-Kjeldahl method, and Soxhlet extraction, respectively, following AOAC methods (11). Each value of proximate composition was the mean of measurements for three separate fish.

FA composition analysis. Lipids for FA composition analysis were extracted from the minced catfish samples according to the method described in a previous report (10). The extracted lipids were transferred to a 20-mL test tube with Teflon cap, flushed with nitrogen, and stored at $-40^{\circ} \mathrm{C}$. FAME were prepared using $0.5 \mathrm{~g}$ fish lipids according to AOCS Method Ce 2-66 (12). Hexane containing FAME was transferred into a 4-mL vial with a Teflon cap, flushed with nitrogen and stored at $-40^{\circ} \mathrm{C}$ until analysis by GLC. FAME were analyzed using GLC as described in a previous report (13). Each value of FA composition was the mean of measurements for three separate fish.

Fish sample preparation for lipid oxidation and hydrolysis measurements. Catfish caught in December 1999 were used for analyses of PV, thiobarbituric acid (TBA) value, and FFA. Muscle collected from 50 catfish was minced and mixed together. Minced muscle was divided into three portions. Ascorbic acid $(0.5 \%$ on the basis of fish sample weight) was mixed into one of the portions. Patties (40 g, $4 \mathrm{~cm}$ diameter) were prepared with the minced fish muscle with and without ascorbic acid. Separately, muscle and viscera were collected from 15 catfish. The mixture of muscle and viscera was minced. Patties were prepared from the minced mixture of muscle and viscera in the same manner as with the muscle. The patties prepared from one portion of minced muscle without ascorbic acid, the muscle patties with ascorbic acid, and the mixture patties were stored at $2^{\circ} \mathrm{C}$ for $12 \mathrm{~d}$. The patties from the other portion of minced muscle without ascorbic acid were stored at $-14^{\circ} \mathrm{C}$ for 9 wk. The patties were stored open to the air on a plate covered with aluminum foil.

Measurements of PV, TBA value, and FFA content. Three patties of each sample were taken for each measurement of PV, TBA value, and FFA content on every third day for the samples stored at $2^{\circ} \mathrm{C}$ and every week or two for the sample stored at $-14^{\circ} \mathrm{C}$. PV, TBA value, and FFA content were determined by AOCS Method Cd 8-53 (12) and the methods of Lemon (14) and Ke and Woyewoda (15), respectively, with minor modifications suggested by Hwang and Regenstein (7).

Statistical analysis. Values of lipid contents and FA compositions between the muscle and the mixture of muscle and viscera were compared by a paired two-tailed $t$-test at $\alpha=0.05$.

\section{Results and Discussion}

Proximate composition of catfish. Lipid contents of catfish muscle ranged from $2.5 \%(\mathrm{w} / \mathrm{w})$ to $3.8 \%$ (Table 1$)$. Incorporation of viscera into the muscle increased the lipid content $(4.5-5.9 \%)$ significantly $(\alpha=0.05)$. Winter catfish samples showed slightly higher lipid contents than summer samples without statistical significance (Table 1). Seasonal variation of lipid contents in catfish was not as distinct as that observed in fatty saltwater fish. For comparison, Leu et al. (6) reported that lipid contents in mackerel varied with season, ranging $3.8-13.4 \%$ in light muscle, $7.5-19.1 \%$ in dark muscle, and $13.7-23.7 \%$ in belly flap with higher lipid contents with approaching winter. Moisture and protein contents in catfish were significantly $(\alpha=0.05)$ higher in the muscle than in the mixture (Table 1). The minimal seasonal variation of lipid contents in catfish was consistent with the previous reports by Nettleton et al. (2) and Mustafa and Medeiros (8).

Table 1. Proximate Composition of Korean Catfish

\begin{tabular}{lllll}
\hline Sample type & Date of sampling & Moisture $(\%)$ & Crude fat $(\%)$ & Crude protein $(\%)$ \\
\hline Muscle & September 1999 & $79.2 \pm 0.22^{*}$ & $2.9 \pm 0.33$ & $16.5 \pm 0.12$ \\
& October 1999 & $78.1 \pm 0.43$ & $3.6 \pm 0.34$ & $16.4 \pm 0.46$ \\
& November 1999 & $77.9 \pm 0.28$ & $3.2 \pm 0.25$ & $16.6 \pm 0.21$ \\
& December 1999 & $78.1 \pm 0.39$ & $3.5 \pm 0.28$ & $15.8 \pm 0.31$ \\
& January 2000 & $78.1 \pm 0.44$ & $3.4 \pm 0.30$ & $15.9 \pm 0.28$ \\
& March 2000 & $78.2 \pm 0.32$ & $3.8 \pm 0.20$ & $16.1 \pm 0.23$ \\
& May 2000 & $78.2 \pm 0.49$ & $3.0 \pm 0.28$ & $16.6 \pm 0.34$ \\
July 2000 & $78.9 \pm 0.14$ & $2.5 \pm 0.31$ & $16.3 \pm 0.35$ \\
Mixture of muscle & Mean & $78.3 \pm 0.46 * *$ & $3.2 \pm 0.42$ & $16.2 \pm 0.19$ \\
& September 1999 & $79.4 \pm 0.69$ & $5.2 \pm 0.56$ & $16.1 \pm 0.25$ \\
& October 1999 & $77.0 \pm 1.43$ & $5.7 \pm 0.50$ & $16.3 \pm 0.38$ \\
& November 1999 & $76.5 \pm 0.94$ & $5.4 \pm 0.40$ & $15.5 \pm 0.34$ \\
& December 1999 & $77.2 \pm 0.07$ & $5.7 \pm 0.05$ & $15.9 \pm 0.44$ \\
& January 2000 & $77.2 \pm 0.35$ & $5.6 \pm 0.06$ & $15.5 \pm 0.10$ \\
& March 2000 & $77.0 \pm 0.29$ & $5.9 \pm 0.32$ & $16.0 \pm 0.36$ \\
& May 2000 & $77.6 \pm 0.42$ & $5.2 \pm 0.45$ & $15.9 \pm 0.31$ \\
\hline
\end{tabular}

\footnotetext{
* Mean \pm SD of measurements for three fish.

** Mean \pm SD of eight values.
} 
FA composition of catfish lipids. Major FA of catfish muscle lipids were oleic acid [27-31\% (w/w) of total FA], palmitic acid (19-22\%), and linoleic acid (11-14\%) (Table 2). EPA and DHA were $2.7-3.7 \%(\mathrm{w} / \mathrm{w})$ and $4.4-9.4 \%$, respectively, in catfish muscle. These data indicate that catfish are a good source of n-3 FA, although the contents of EPA and DHA in catfish were lower than those in mackerel; Hwang and Regenstein (10) reported that mackerel lipids contained $4-5 \%$ EPA and $8-10 \%$ DHA. Incorporation of viscera into the muscle resulted in a significant reduction $(\alpha=$ $0.05)$ of oleic acid (24-29\%) and palmitic acid (19-22\%) and increase of EPA (3.0-4.1\%) and DHA (5.4-10.8\%) (Table 3). Linoleic acid did not show a significant difference between the muscle and the mixture $(\alpha=0.05)$. No pattern of seasonal variation in FA composition of catfish lipids was apparent, although the November and December samples were a little higher in EPA (3.0-3.5\%) and DHA (8.1-10.8\%) (Tables 2,3$)$. Although no significant difference $(\alpha=0.05)$ was observed in the levels of total saturated FA between the muscle $(28.5 \%)$ and the mixture of muscle and viscera $(28.8 \%)$, total monounsaturated FA levels significantly decreased (45.3\% vs. $42.5 \%)$ and total PUFA levels increased with the incorporation of viscera ( $25.2 \mathrm{vs.} 27.6 \%)$.

Lipid oxidation and hydrolysis in minced catfish. Lipid oxidation was determined by PV and TBA values. PV of minced catfish muscle reached its highest value on day 9 during the refrigerated storage at $2^{\circ} \mathrm{C}$ (Fig. 1). TBA values of the minced muscle increased continuously during the 12-d storage at $2^{\circ} \mathrm{C}$ (Figure 2). TBA values of the minced samples stored at $2^{\circ} \mathrm{C}$ were not measured after $12 \mathrm{~d}$ since in practical use minced fish may not be stored more than a week at a refrigerated temperature. The drop in PV on day 12 was likely due to a faster rate of decomposition of peroxides than of their production, rather than to a complete cessation of oxidation. Incorporation of viscera into the muscle showed higher PV and TBA values, presumably mainly due to the higher content (Table 1) and polyunsaturation (Tables 2,3) of the lipids in the mixture of muscle and viscera than in those of muscle in catfish. Addition of ascorbic acid markedly retarded lipid oxidation in the catfish muscle mince as shown in Figures 1 and 2. Hwang and Regenstein (7) reported ascorbic acid also had strong antioxidant activity on minced menhaden lipids in comparison with various commercial antioxidant products containing tocopherols, rosemary extracts, citric acid, and TBHQ. Frozen storage at $-14^{\circ} \mathrm{C}$ reduced lipid oxidation in the catfish muscle mince as shown in Figures 1 and 2, although lipid oxidation in minced catfish continuously increased during a long-term frozen storage: PV and TBA values were $1.19 \pm 0.06$ mequiv peroxide $/ \mathrm{kg}$ sample and $0.38 \pm 0.01 \mu \mathrm{mol}$ malonaldehyde/g sample, respectively, at the ninth week during the frozen storage (figures are not shown). Hwang and Regenstein (7) suggested a combination of vacuum packaging with frozen storage as the best way to protect lipids in fatty fish from oxidation.

Table 2. FA Composition (\%, w/w) of Lipids Extracted from Muscle of Korean Catfish

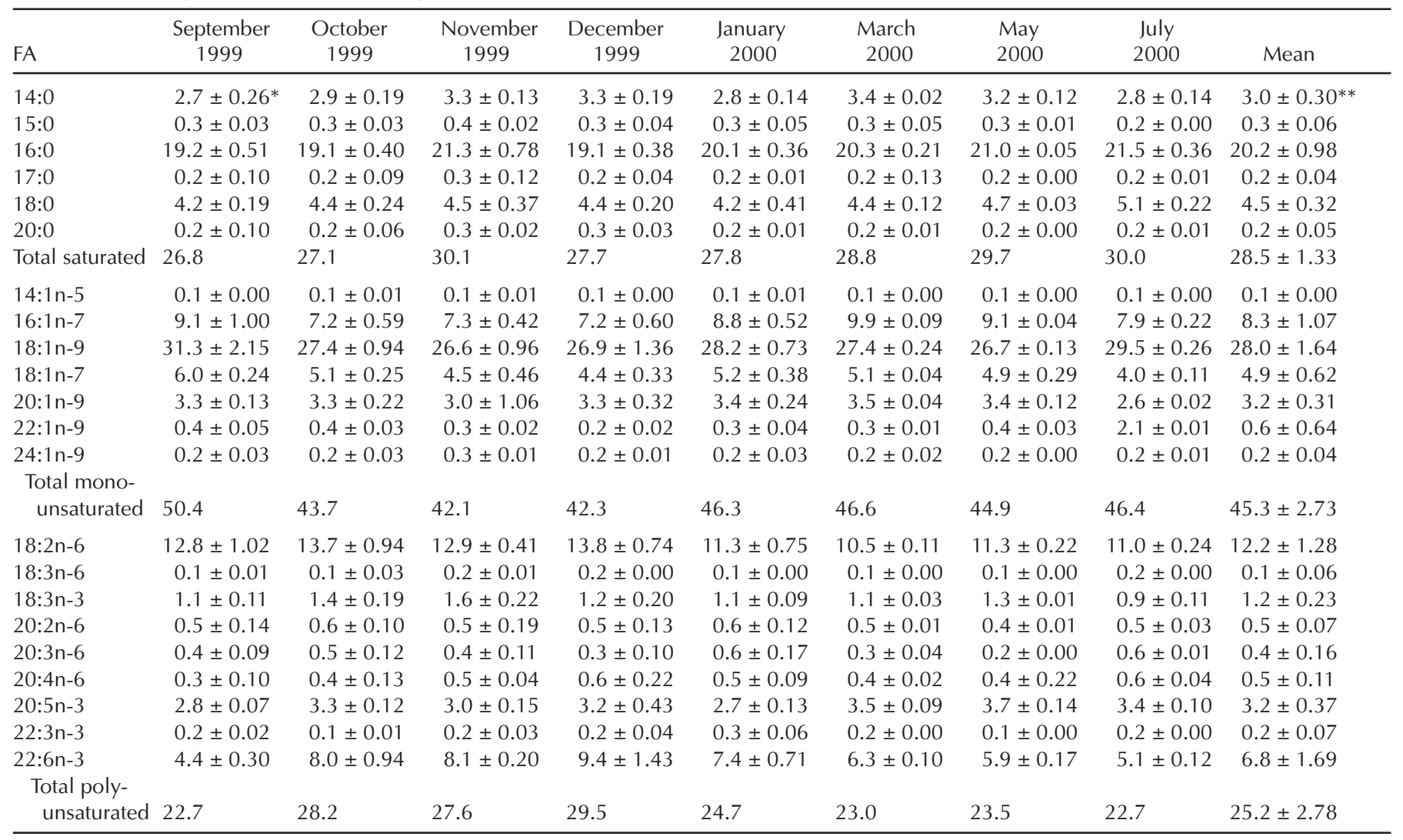

$*$ Mean \pm SD of measurements for three fish.

** Mean \pm SD of eight values. 


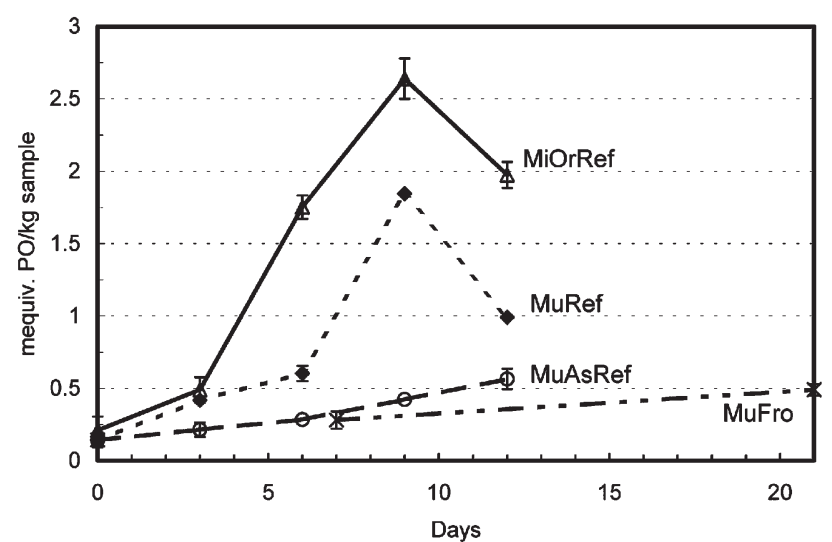

Figure 1. Changes in PV of minced catfish during storage. Point and bar represent mean and $\mathrm{SD}$ of measurements for three patties. $\mathrm{PO}$, peroxide; MuRef, muscle stored at $2^{\circ} \mathrm{C}$; MuAsRef, muscle to which was added $0.5 \%$ ascorbic acid, with storage at $2^{\circ} \mathrm{C}$; MiOrRef, mixture of muscle and viscera stored at $2^{\circ} \mathrm{C}$; and MuFro, muscle stored at $-14^{\circ} \mathrm{C}$.

FFA in minced catfish muscle increased with time during the $2^{\circ} \mathrm{C}$ storage (Figure 3 ). Incorporation of viscera into muscle greatly accelerated FFA production during refrigerated storage. This indicates that lipolytic enzymes were more abundant in viscera than in muscle, considering that FFA in fish are largely produced from lipids by hydrolytic enzymes present in muscle and viscera (16). The catfish muscle with ascorbic acid showed higher FFA values com-

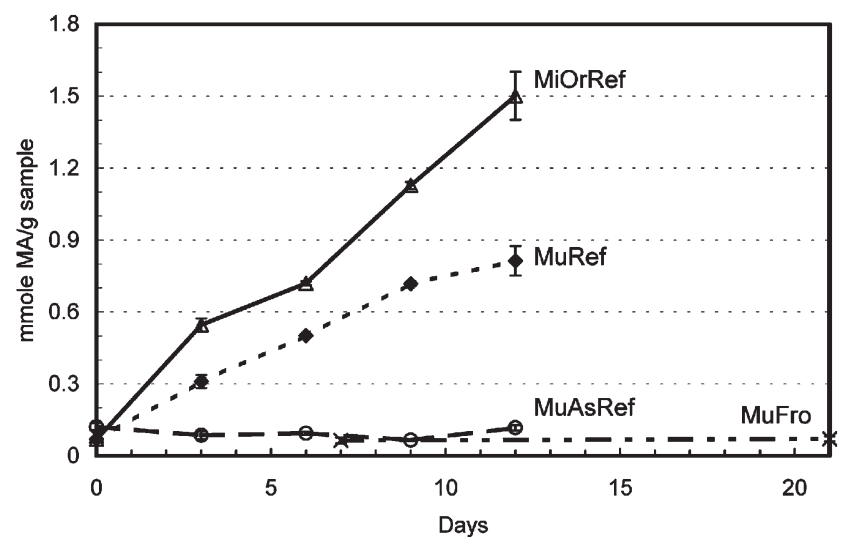

Figure 2. Changes in thiobarbituric acid values of minced catfish during storage. Point and bar represent mean and SD of measurements for three patties. MA, malonaldehyde; for other abbreviations see Figure 1.

pared with the similar sample without ascorbic acid (Figure 3). The higher FFA values in the sample to which ascorbic acid was added might have resulted from the acidity of the added ascorbic acid. Frozen storage lowered FFA production in catfish (Fig. 3), although lipolytic enzymes in fish have been known to be active even at $-20^{\circ} \mathrm{C}$ (17). In this study, FFA were continuously produced during the $-14^{\circ} \mathrm{C}$ storage and reached $11.7 \pm 1.2 \mu \mathrm{mol} / \mathrm{g}$ sample at the

Table 3. FA Composition (\%, w/w) of Lipids Extracted from the Mixture of the Muscle and Viscera of Korean Catfish

\begin{tabular}{|c|c|c|c|c|c|c|c|c|c|}
\hline FA & $\begin{array}{c}\text { September } \\
1999\end{array}$ & $\begin{array}{l}\text { October } \\
1999\end{array}$ & $\begin{array}{c}\text { November } \\
1999\end{array}$ & $\begin{array}{l}\text { December } \\
1999\end{array}$ & $\begin{array}{c}\text { January } \\
2000\end{array}$ & $\begin{array}{c}\text { March } \\
2000\end{array}$ & $\begin{array}{l}\text { May } \\
2000\end{array}$ & $\begin{array}{l}\text { July } \\
2000\end{array}$ & Mean \\
\hline $14: 0$ & $2.6 \pm 0.15^{* *}$ & $3.0 \pm 0.18$ & $3.4 \pm 0.03$ & $3.4 \pm 0.08$ & $2.7 \pm 0.02$ & $3.9 \pm 0.13$ & $3.5 \pm 0.11$ & $3.1 \pm 0.26$ & $3.2 \pm 0.44^{* *}$ \\
\hline $15: 0$ & $0.2 \pm 0.01$ & $0.3 \pm 0.02$ & $0.5 \pm 0.02$ & $0.4 \pm 0.01$ & $0.3 \pm 0.05$ & $0.4 \pm 0.01$ & $0.3 \pm 0.03$ & $0.3 \pm 0.01$ & $0.4 \pm 0.10$ \\
\hline $17: 0$ & $0.1 \pm 0.02$ & $0.2 \pm 0.01$ & $0.4 \pm 0.01$ & $0.3 \pm 0.05$ & $0.2 \pm 0.01$ & $0.3 \pm 0.08$ & $0.2 \pm 0.19$ & $0.2 \pm 0.00$ & $0.3 \pm 0.10$ \\
\hline 18:0 & $3.8 \pm 0.07$ & $4.2 \pm 0.09$ & $4.7 \pm 0.05$ & $4.4 \pm 0.10$ & $4.2 \pm 0.33$ & $4.5 \pm 0.20$ & $4.9 \pm 0.22$ & $5.5 \pm 0.18$ & $4.5 \pm 0.52$ \\
\hline $20: 0$ & $0.2 \pm 0.01$ & $0.2 \pm 0.07$ & $0.3 \pm 0.01$ & $0.3 \pm 0.01$ & $0.2 \pm 0.01$ & $0.2 \pm 0.00$ & $0.2 \pm 0.01$ & $0.2 \pm 0.01$ & $0.2 \pm 0.05$ \\
\hline $16: 1 n-7$ & $9.7 \pm 0.90$ & $7.4 \pm 0.39$ & $7.8 \pm 0.33$ & $7.7 \pm 0.44$ & $8.8 \pm 0.32$ & $8.5 \pm 0.21$ & $8.8 \pm 0.34$ & $8.4 \pm 0.26$ & $8.4 \pm 0.75$ \\
\hline $18: 1 n-9$ & $28.5 \pm 1.132$ & $3.8 \pm 0.87$ & $24.8 \pm 0.77$ & $24.0 \pm 1.68$ & $26.0 \pm 0.42$ & $24.3 \pm 0.41$ & $26.1 \pm 0.25$ & $27.1 \pm 0.46$ & $25.6 \pm 1.65$ \\
\hline $18: 1 n-7$ & $5.7 \pm 0.19$ & $4.7 \pm 0.12$ & $4.4 \pm 0.10$ & $4.3 \pm 0.12$ & $5.6 \pm 0.09$ & $4.8 \pm 0.30$ & $3.8 \pm 0.21$ & $4.2 \pm 0.19$ & $4.7 \pm 0.67$ \\
\hline $20: 1 n-9$ & $3.5 \pm 0.11$ & $3.5 \pm 0.05$ & $2.5 \pm 1.83$ & $3.3 \pm 0.22$ & $3.4 \pm 0.02$ & $3.3 \pm 0.19$ & $3.4 \pm 0.08$ & $2.8 \pm 0.05$ & $3.2 \pm 0.35$ \\
\hline $22: 1 n-9$ & $0.5 \pm 0.01$ & $0.4 \pm 0.03$ & $0.2 \pm 0.01$ & $0.2 \pm 0.01$ & $0.3 \pm 0.03$ & $0.3 \pm 0.03$ & $0.3 \pm 0.00$ & $0.2 \pm 0.01$ & $0.3 \pm 0.12$ \\
\hline $24: 1 n-9$ & $0.2 \pm 0.02$ & $0.3 \pm 0.24$ & $0.2 \pm 0.01$ & $0.2 \pm 0.00$ & $0.2 \pm 0.04$ & $0.2 \pm 0.01$ & $0.2 \pm 0.00$ & $0.2 \pm 0.01$ & $0.2 \pm 0.04$ \\
\hline $18: 3 n-3$ & $1.2 \pm 0.09$ & $1.5 \pm 0.10$ & $1.4 \pm 0.03$ & $1.4 \pm 0.04$ & $1.1 \pm 0.01$ & $1.1 \pm 0.11$ & $1.2 \pm 0.09$ & $0.9 \pm 0.13$ & $1.2 \pm 0.22$ \\
\hline $20: 2 n-6$ & $0.7 \pm 0.05$ & $0.8 \pm 0.02$ & $0.5 \pm 0.30$ & $0.8 \pm 0.04$ & $0.8 \pm 0.03$ & $0.7 \pm 0.02$ & $0.5 \pm 0.01$ & $0.8 \pm 0.19$ & $0.7 \pm 0.10$ \\
\hline $20: 3 n-6$ & $0.4 \pm 0.08$ & $0.4 \pm 0.05$ & $0.4 \pm 0.02$ & $0.4 \pm 0.07$ & $0.9 \pm 0.07$ & $0.4 \pm 0.05$ & $0.3 \pm 0.01$ & $0.7 \pm 0.12$ & $0.5 \pm 0.18$ \\
\hline $20: 4 n-6$ & $0.4 \pm 0.03$ & $0.4 \pm 0.05$ & $0.7 \pm 0.02$ & $0.8 \pm 0.22$ & $0.7 \pm 0.01$ & $0.7 \pm 0.08$ & $0.5 \pm 0.03$ & $0.8 \pm 0.04$ & $0.6 \pm 0.13$ \\
\hline $20: 5 n-3$ & $3.3 \pm 0.15$ & $3.6 \pm 0.11$ & $3.0 \pm 0.04$ & $3.5 \pm 0.42$ & $3.0 \pm 0.09$ & $3.9 \pm 0.20$ & $4.1 \pm 0.10$ & $3.9 \pm 0.30$ & $3.5 \pm 0.44$ \\
\hline $22: 3 n-3$ & $0.1 \pm 0.01$ & $0.2 \pm 0.01$ & $0.3 \pm 0.01$ & $0.3 \pm 0.04$ & $0.3 \pm 0.00$ & $0.3 \pm 0.00$ & $0.2 \pm 0.00$ & $0.2 \pm 0.01$ & $0.3 \pm 0.08$ \\
\hline $22: 6 n-3$ & $5.4 \pm 0.10$ & $8.9 \pm 0.55$ & $8.9 \pm 0.19$ & $10.8 \pm 1.8$ & $48.4 \pm 0.51$ & $8.2 \pm 0.32$ & $7.6 \pm 0.30$ & $6.9 \pm 0.16$ & $8.1 \pm 1.61$ \\
\hline $\begin{array}{l}\text { Total poly- } \\
\text { unsaturated }\end{array}$ & 25.6 & 30.2 & 27.8 & 30.7 & 27.1 & 27.5 & 26.4 & 25.6 & $27.6 \pm 1.92$ \\
\hline
\end{tabular}

* Mean \pm SD of measurements for three fish.

** Mean \pm SD of eight values. 


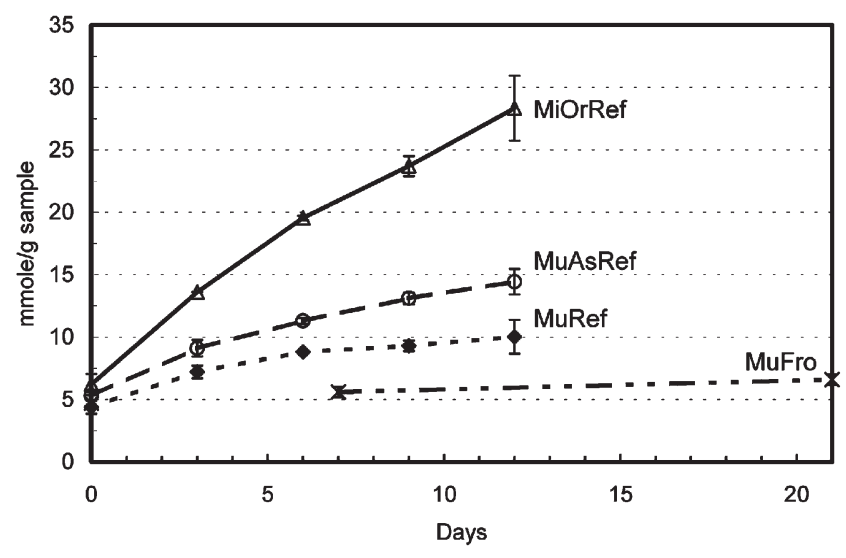

Figure 3. Changes in FFA of minced catfish during storage. Point and bar represent mean and SD of measurements for three patties. For abbreviations see Figure 1.

ninth week (data not shown). According to Hwang and Regenstein (7), vacuum packaging did not protect lipids in fish from hydrolysis. However, heat may readily deactivate lipolytic enzymes in the fish. Olley and Lovern (18) reported that lipid hydrolysis was negligible in cod stored at $0^{\circ} \mathrm{C}$ after cooking, and Hwang and Regenstein (10) observed that cooked mackerel did not change its content of DAG and FFA during refrigerated storage.

\section{Acknowledgments}

This work was supported in part by the Korea Science and Engineering Foundation through the Food Industrial Technology Research Center at Mokpo National University. This article is recorded as Journal Series No. 13571, Agricultural Research Division, Institute of Agriculture and Natural Resources, University of Nebraska-Lincoln.

\section{References}

1. P. Chanmugam, M. Boudreau, and D. H. Hwang, Differences in the $\omega-3$ Fatty Acid Contents in Pond-Reared and Wild Fish and Shellfish, J. Food Sci. 51:1556-1557 (1986).

2. J. A. Nettleton, W. H. Allen, Jr., L. V. Klatt, W. M. N. Ratnayake, and R. G. Ackman, Nutrients and Chemical Residues in One- to Two-Pound Mississippi Farm-Raised Channel Catfish (Ictalurus punctatus), J. Food Sci. 55:954-958 (1990).

3. M. C. Erickson, Variation of Lipid and Tocopherol Composition in Three Strains of Channel Catfish (Ictalurus punctatus), J. Sci. Food Agric. 59:529-536 (1992).
4. J. H. Choi, S. H. Park, J. I. Ro, and J. H. Pyeun, Distribution of Lipid Components in Various Tissues of Catfish, Parasilurus asotus, Korean J. Food Sci. Technol. 17:15-20 (1985).

5. C. A. Morris, K. C. Haynes, J. T. Keeton, and D. M. Gatlin, Fish Oil Dietary Effects on Fatty Acid Composition and Flavor of Channel Catfish, J. Food Sci. 60:1225-1227 (1995).

6. S.-S. Leu, S. N. Jhaveri, P. A. Karakoltsidis, and S. N. Konstantinides, Atlantic Mackerel (Scomber scombrus L.): Seasonal Variation in Proximate Composition and Distribution of Chemical Nutrition, J. Food Sci. 46:1635-1638 (1981).

7. K. T. Hwang, and J. M. Regenstein, Protection of Menhaden Mince Lipids from Rancidity During Frozen Storage, J. Food Sci. 54:1120-1124 (1989).

8. F.A. Mustafa and D. M. Medeiros, Proximate Composition, Mineral Content, and Fatty Acids of Catfish (Ictalurus punctatus, Rafinesque) for Different Seasons and Cooking Methods, J. Food Sci. 50:585-588 (1985).

9. S. Sathivel, W. Prinyawiwatkul, C. C. Grimm, J. M. King, and S. Lloyd, FA Composition of Crude Oil Recovered from Catfish Viscera, J. Am. Oil Chem. Soc. 79:989-992 (2002).

10. K. T. Hwang and J. M. Regenstein, Characteristics of Mackerel Mince Lipid Hydrolysis, J. Food Sci. 58:79-83 (1993).

11. AOAC, Official Methods of Analysis of the Association of Official Analytical Chemists, 13th edn., Association of Official Analytical Chemists, Washington, DC, 1984.

12. AOCS, Official Methods and Recommended Practices of the American Oil Chemists' Society, 4th edn., American Oil Chemists' Society, Champaign, 1989, Methods Ce 2-66, Cd 8-53.

13. K. T. Hwang, J. S. Hong, J. S. Yang, H. S. Sohn, and C. L. Weller, Detection of Alkanes and Alkenes for Identifying Irradiated Cereals, J. Am. Oil Chem. Soc. 78:1145-1149 (2001).

14. D. W. Lemon, An Improved TBA Test for Rancidity, in New Series Circular Number 51, Fisheries and Marine Services Canada, Halifax, Nova Scotia, 1975.

15. P. J. Ke and A. D. Woyewoda, A Titrimetric Method for Determination of Free Fatty Acids in Tissues and Lipids with Ternary Solvents and $m$-Cresol Purple Indicator, Anal. Chim. Acta 99: 387-391 (1978).

16. R. Hardy, A. S. McGill, and F. D. Gunstone, Lipid and Antioxidative Changes in Cold Stored Cod, J. Sci. Food Agric. 17:112-117 (1979).

17. T. Ohshima, S. Wada, and C. Koizumi, Preferential Enzymatic Hydrolysis of Phosphatidylchloine in Skipjack Flesh During Frozen Storage, Bull. Jpn. Soc. Sci. Fish. 50:20912098 (1984).

18. J. Olley and J. A. Lovern, Phospholipid Hydrolysis in Cod Flesh Stored at Various Temperatures, J. Sci. Food Agric. 11: 644-652 (1960). 